\title{
Mass Media and Community's Communication Sovereignty
}

\author{
Petrus Ana Andung \\ Faculty of Social and Political Science \\ Nusa Cendana University \\ Kupang, Indonesia \\ petrusanaandung@staf.undana.ac.id \\ Aloysius Liliweri \\ Faculty of Social and Political Science \\ Nusa Cendana University \\ Kupang, Indonesia
}

\author{
Dian Wardiana Sjuchro \\ Faculty of Communication Science \\ Padjadjaran University \\ Jatinangor, Indonesia \\ Purwanti Hadisiwi \\ Faculty of Communication Science \\ Padjadjaran University \\ Jatinangor, Indonesia
}

\begin{abstract}
Communities who live in the border areas of Indonesia (Napan Village, Timor Tengah Utara District, East Nusa Tenggara Province) and Bobometo Village, Timor Leste (District Oecusse) consume television in a very unique way. Although they are Timor Lestean, people in Bobometo watch Indonesian television. In contrast the Napan community, in addition to watching television from Indonesia, also often view television broadcasts from Timor Leste. The presence of television has a very strategic role in this border society. Preliminary study results revealed that the existence of television in these two villages, creating a new dependence on television. The border communities are very active in using television media. They spend at least 5 to 8 hours a day in average to watch television. This article aims to discuss how the communication sovereignty of border communities in Napan and Bobometo because of the existence of television in their daily lives. This research uses media ethnography method. The results show that firstly, television in the perspective of media ethnography has become an inseparable part of the daily routine of audiences. Television recognizes social union with audiences. The existence of television is similar to the existence of other objects such as vehicles, watches, washing machines, and other useful objects. Like a ritual, they interact with television every day. Secondly, the audiences in the border areas are controlled by information that presented from television. Thirdly, there is lack of communication sovereignty of these communities in doing "resistance" to the transmission and acceptance from outside the national territory.
\end{abstract}

Keywords-television; media ethnography; border society; communication sovereignty

\section{INTRODUCTION}

Communities who live in the border areas of Indonesia (Napan Village, North Central Timor District, East Nusa
Tenggara Province) and Bobometo Village, Timor Leste (District Oecusse) consume television (TV) in a very unique way. Preliminary studies show that although they are Timor Lestean, people in Bobometo watch Indonesian television intensively. In contrast the Napan community, in addition to watching television from Indonesia, also often view television broadcasts from Timor Leste.

Sociologically and genealogically, the border society of Indonesia and Timor Leste according to research of Robot has a rope fraternity. The spirit of social interaction between them is not receding, although under the watchful eye of the security forces of the two countries concerned [1].

This close sense of kinship is the trigger for communicating with one another, especially in every custom ritual. Even to convey family information such as death or wedding invitations, this border people are willing to break through national borders without pocketing official permission. These kinship relationships then underlie Timor Lestean people in District Oecusse including Suco Bobometo identify themselves as atoni pah meto (West Timorese) people who are commonly used as a general term for ethnic in West Timor including Napan Village, Indonesia.

This article aims to analyze the pattern of TV consumption in border communities in Napan and Bobometo villages, and to analyze how is the communication sovereignty of border communities in Napan and Bobometo because of the existence of television in their daily lives.

\section{Methodology}

The method of this research is media ethnography. As a research method, the main focus of media ethnography is everyday life (daily life) and media usage. Daily life is 
intended not only to refer to various daily routine activities but also related to social values. It is also a place where places and spaces where technology and social values meet [2].

As a method, media ethnography is divided into two categories; namely media ethnography with focuses on audience, and media ethnography for media production. Media ethnography in relation to audience (audience ethnography) focuses on media receptions (media meaning) and media usage. Based on these two categories, the media ethnography method in this research is categorized as audience ethnography [3].

Data collection in this research was done by using in-depth interview, Focus Group Discussion, Participatory Rural Appraisal (PRA), and participant observation techniques. Informants in this study were 30 television users whose age was above 18 years. Data analysis followed the six steps according to Creswell [4] starting from field data collection for analysis, coding, create themes, present report in the form of a qualitative description or narrative, and lastly interpret the available data.

\section{FINDINGS}

\section{A. The Pattern of TV Consuming of the Border Society}

1) Watching Television Together to tighten Social Kinship

Watching TV in this border community is a necessity. This is due to the limitations of other entertainment sources in the village besides TV. Based on the field data, it known that there is a bit difference between these two communities in terms of watching TV patterns. People in Napan Village, Indonesia generally watch TV broadcasts with their own family members. As one of local leaders, Gregorius Siki (Interview, Napan, Indonesia, June 13, 2017) said, "From the early morning, my children [grandchildren] before school they had to watch TV first. Later on, during school hours, I watch TV alone. Afternoon my wife accompany me. We will watch together in front of TV at night".

Napan people considered watching TV as a momentum to build quality time with family members. "We watch TV together with our family so that we may intensively talk one and another. We can gather together in front of TV. Before owning TV, after dinner, every family member immediately enter each bedroom. Now there is time together "(Antonina Siki, interview, Napan, Indonesia, July 17, 2017).

The pattern of watching TV was found differently in Suco Bobometo, Timor Leste. They watch TV assembled at nearby houses that have TV. Even some of them must be walking 1 kilometer from their home just to watch TV. As found, every home that own TV puts TV on the outside of the home as open space to public. Thus, everyone can freely watch TV at any time.

"In our village here, every house hold has not own TV yet. Although, there is electricity but no TV. So, for those who have no TV, he/she has to search for nearest neighbors. To let people feel free to watch TV, I put my TV outside" (Serafinus Kolo, interview, Bobometo, Timor Leste, Oct. 12, 2017).
Watching TV together for Bobometo people is a kind to foster social kinship. "... If you just watch alone, it less funny. It's not exciting. By watching together, we will have good relations with neighbors "(Filemena Ulan, interview, Bobometo, Timor Leste, Sept. 5, 2017). The same opinion was shared by other informants during the FGD that watching together with the neighbors guarded and strengthened friendly relations among them. This is because not all residents have their own TV because of the economic limitations of the society.

2) TV as an Inseparable Part of the Daily Routine of Audiences

Being in front of the TV and listening to favorite programs, is a routine activity of the border society of Indonesia and Timor Leste. The similarity of TV consumption pattern among these people is in terms of TV schedules. As found that the community schedule often adjusts to the schedule of TV programs. This is mainly for their favorite or favorite TV programs.

Not a few who have to adjust their activities either as housewives or farmers with the schedule of TV. As one informant, Florina Siki, in a discussion using Participatory Rural Appraisal (PRA) technique said that she is only trying to fulfill her domestic activities such as cooking or cleaning the house on the sidelines of the commercial break. Even while doing gardening activities and her favorite film is showing, she go home as soon as possible to watch TV.

"We keep cooking on the sidelines watching. Later during commercial break, we ran quickly to the kitchen. Make fire and load water for rice. A few minutes later, we back to continue watching. When commercial break again, we check our cooking... hahahaha [laughs]. Even if there is work in the garden, We stop working and go home quickly to watch our favorite movie,..” (Florina Siki, Discussion PRA, Napan, Indonesia, Aug. 30, 2017).

The same opinion also appeared in discussions with the Bobometo community. One informant revealed that he and his friend as a mason always stop working if their favorite show aired on TV. "When Indian movie is showing in the afternoon, we stop working. We watch TV. Once the TV program is finished, we continue our working again" (Dominikus Kolo, Bobometo, Timor Leste, interview, Sept. 11, 2017).

Based on the statement of informants then it is known that TV has undergone a process of unification with the community. The schedule of the media has affected the daily schedule or agenda of the community. The position of TV can no longer be separated from the routine of daily life of society. Media becomes an integral part of the border community.

\section{B. Communication Sovereignty of the Community}

Communication sovereignty refers to the weakening of 'resistance' efforts of citizens or audiences of various information on the transmission and reception of mass media including TV from outside the national territory [5]. Thus, society becomes powerless against the exposure of messages from foreign media. As a result, the symbols of communication 
are taken for granted because of their limited media literacy capabilities.

Generally, the border society imitates of what is seen on TV due to the presence of TV. Adult women in Napan, Indonesia claim that they imitated the fashion style of Indians as seen in Indian films on ANTV. Impersonation occurs primarily in accessories such as starting to use scarves, many bracelets on hand and earrings. In fact, a dance teacher at a primary school in Napan, Indonesia said, "I'm a dance coach. I take good things from Indian dance then I teach my student in Dance Studio. We often practice Koi Miligaya Dance and performed it outside the village" (Monika Bobo, Napan, Indonesia, interview, June 24, 2017).

While in Bobometo Village, Timor Leste, the imitation of audiences also occurred in their favorite soap opera such as Anak Jalanan and Sinetron Anak Langit soap operas. "We at Bobometo are very fanatic with the movie of Boy Reva [Anak Jalanan]. Many people here bought Reva Boy T-shirts. Most children and parents wear that T-shirt. Some people bought big motorcycle like Boy's motorcycle in this soap opera" (Sekundia Beli, Bobometo, Timor Leste, interview, Oct. 3, 2017).

Not only imitation, people also consider their favorite TV programs as a reference in their real lives. Bobometo people, for instance, take into account the Indonesian $\mathrm{TV}$ as an economic reference in running the border business. They get information on dollar exchange rate against Rupiah through Indonesian Metro TV. In contrast, Timor Leste's TV was also watched by Napan villagers in order to know the development of the neighboring country.

\section{Communication Actions of the Audience}

The presence and incorporation of television programs with the routine of community life on the border society, has implications for the emergence of their communication actions. As it is known that the most favorite TV program for this community is Indian films on Indonesian television station, ANTV. The high penetration of Indian films in daily lives of audiences in Napan Village, Indonesia and Bobometo Village, East Timor, has implications for the emergence of communication action. It was found that communication actions between Napan and Bobometo villages were found different from each other.

The communication action of audiences in Napan, Indonesia especially for women is changing their appearance to resemble the cast characters in Indian films. Female informants confess that they often use various accessories that resemble what is seen in Indian films.

"I often go to school, put a small dot on the forehead like Indian girls. But I do it by using marker hahahahaha (laugh)" (Istiana, FGD, Napan, Indonesia, Aug. 10, 2017).

The same thing was conveyed by other informants as follows:

"We also imitate from Indian Film in terms of tidiness. Currently, we, moms in Napan, have started wearing a lot of jewelry when we go to party. We also wear many bracelets on hand, gold rings, and big round and long earrings, But we do it when we go to the party only" (Antonina, PRA, Napan, Indonesia, Aug. 30, 2017).

In addition to performing imitation resembling Indian women, other communication actions undertaken by the Napan Village community are adapting Indian dances. Newly modified dances following Indian dance movements are getting familiar in the community. Even it have been taught in elementary school as a modern dance performed during the independence ceremony of the Republic of Indonesia.

"I myself am working as a teacher at a primary school in Napan. We take good points and learn from Indian films especially Indian dances. We practice and teach it to my children at school. We taught the children Tari Gong dance but modified with Indian movements to be performed at the Independence Day, Even, the children were asked also for wearing long scarf like Sari in Indian films" (Brigitha Nulle, Napan, Indonesia, Interview, July 19, 2017).

Meanwhile, the Bobometo Village community, Timor Leste has different communication actions due to the presence of Indian films. Most of the informants, both male and female, admitted that they became more concerned with their neighbors especially after watching Indian films on Indonesian television station, ANTV.

"... Indian films are almost provided the similar story. They are very concerned with others. I take some benefits messages from that film. Because of Indian Film, I become intrigued to be more care of others. Moreover, life in Bobometo is still difficult. Prices of goods and food are still expensive. As a consequence, we must be take care of our neighbors". (Sekundina Beli, Bobometo, Timor Leste, Interview, Oct. 3 2017).

A similar opinion was shared by other informants.

"I became more respectful of my wife. I'm not too brawling and demanding her for all sorts. I also learned to be more care of others because of intensively viewing Indian Film on TV. For example, I more appreciate my assistant. Even though I think my assistant did not work in perfect way, I still respect him" (Dominikus Kolo, Bobometo, Timor Leste, interview, Sept. 11, 2017).

Based on the views of the informants both in Indonesia and Timor Leste, it can be seen that the favorite television programs from Indonesia television stations give a big influence in the life of border communities. What is witnessed through television, influences their daily communication actions. Thus, the high penetration of television, especially private television stations from Indonesia with a variety of entertainment programs affect people's perceptions and behavior. The symbols shown on the television through the programming events serve as references by the border community in these two different countries. 


\section{Discussion}

The presence of media in the daily routine of audiences allows the border community to "see" what is happening out there. Media becomes a means of learning to know the various events in the human life cycle. Through TV, the people can understand variety of surrounding events from economic, social, cultural, ideological, political, and security issues. Therefore, McQuil calls the mass media as a window of events and experiences that broaden our view. Mass media is also windows on events and experience [6].

Viewing TV programs from both Indonesia and Timor Leste are part of daily life of the audiences in this border society. Like a ritual, they spend at least 4-8 hours in watching TV every day. As a consequence, they interact with TV every day.

In line with this, Biagi in Susanto asserted that conventional mass media including TV is still a strong reference for the public in searching for reliable information. The presence of $\mathrm{TV}$ in the border area becomes the main choice of the community either in searching for information or for entertainment purposes [7].

Therefore, TV ownership in the context of border communities is a major requirement. Even TV has been positioned as a tools. Television is a tight part that cannot be separated with a household. Reference [8] stated that the media is a form of expansion of human beings such as cars, clothing, watches and various other objects that become an integral part of human life.

In the context of media ethnography, TV is present as an integral part of society. Between TV and society has undergone a process of unification. Television becomes a technology that is always present in every daily life cycle of society. It is present and then affects the routine of community life.

This union in turn has implications for the emergence of schedule negotiations within the community. Reference [9] stated that people will plan their meal times as well as their outdoor activities as they are or are surrounded by television schedules or agendas that determine the topic of conversation.

The high rate of television penetration, especially the Indonesian television stations in daily life of the border community, it is clear that the mass media precisely television has power to control and manage the community schedule. Society in some ways becomes powerless against television exposure. The existence of television becomes a new power in influencing the routine life of audiences at the border.

Meanwhile, the border community also lacks sufficient in terms of media literacy capability. What is presented by the television is accepted without criticizing it well according to their social and cultural circumstances and context. This is evident from imitation through their favorite programs like Indian films. People in Napan village, Indonesia, especially women tend to imitate the appearance and style of accent and accessories worn by Indian film actress. In addition, the local cultural wealth has also begun to be modified in primary schools. Traditional dances are then changed by adding some movements resembling Indian dances. Similarly, the Bobometo community, East Timor, where imitation is also performed, especially in terms of character figures in Indian films.

Based on this fact it can be said that the border community has lack of communications sovereignty. Communities are powerless in facing of information and or messages that are being received by the television media, especially entertainment programs through movies and soap operas. For Bobometo village, Timor Leste, since they are more controlled by Indonesian TV in their daily life, it is indicated that they are lack of communication sovereignty in doing "resistance" to the transmission and acceptance from outside the national territory as Timor Lestean.

\section{CONCLUSION}

It can be concluded that firstly, TV in the perspective of media ethnography has become an inseparable part of the daily routine of audiences. Television recognizes social union with audiences. The existence of TV is similar to the existence of other objects such as vehicles, watches, washing machines, and other useful objects. Like a ritual, they interact with TV every day. Secondly, the audiences in the border areas are controlled by information that presented from TV. Thirdly, there is lack of communication sovereignty of these communities in doing "resistance" to the transmission and acceptance from outside the national territory.

\section{ACKNOWLEDGMENTS}

This research is supported by Direktorat Riset dan Pengabdian Masyarakat, Direktorat Jenderal Penguatan Riset dan Pengembangan Kementeian Riset, Teknologi, dan Pendidikan Tinggi, Republik Indonesia.

\section{REFERENCES}

[1] M. Robot, “Strategi komunikasi masyarakat perbatasan WNI-Indonesia dan Oecusse Timor Leste [Communication strategy of people of Indonesia and Oecusse East Timor border]”. Kupang: Universitas Nusa Cendana, 2010.

[2] M. Hartmann, "Media ethnography: method, methodology or research philosophy? In Researching Media, Democracy and Participation, N. Carpentier, P. Pruulmann-Vengerfeldt, K. Nordenstreng, M. Hartmann, P. Vihalemm, and B. Cammaerts (Eds.), Tartu University Press, 2006, pp. 251-262.

[3] P.D. Murphy, "Locating media ethnography", in The Handbook of Media Audiences, 1st ed., V. Nightingale (Ed.). Blackwell Publishing Ltd, 2011, pp. 380-401.

[4] J.W. Cresswell, "Research Design: Pendekatan Kualitatif, Kuantitatif, dan Mixed [Research Design: Qualitative, Quantitative, and Mixed Approaches]”. 3rd ed. (Transl. by Achmad Fawaid). Yogyakarta: Pustaka Pelajar, 2013.

[5] I.S. Ibrahim and B.A, Akhmad, "Komunikasi dan Komodifikasi: Mengkaji Media dan Budaya dalam Dinamika Globalisasi [Communication and Comodification: Studying Media and Culture in Globalization Dynamics]”. Jakarta: Yayasan Pustaka Obor Indonesia, 2014.

[6] D. McQuail, “Teori Komunikasi Massa [Mass Communication Theory]”, 6th ed., Jakarta: Salemba Humanika, 2012.

[7] E.H. Susanto, "Media Massa, Pemerintah dan Pemilik Modal [Mass Media, Government, and Capital Owners]”. J. Komun. ASPIKOM, vol. 1, no. 6, pp. 477-484, 2013. 
[8] W. Rivers, J.W. Jensen, and T. Peterson, "Media Massa \& Masyarakat Modern [Mass Media and Modern Society]”. Jakarta: Kencana, 2008.
[9] S. Livingstone and P. Lunt, Talk on Television: Audience Participation and Public Debate. London \& New York: Routledge, 2001. 